\title{
ANALYSIS OF PROJECTED CLIMATE CHANGE FOR HUNGARY USING ENSEMBLES SIMULATIONS
}

\author{
PONGRÁCZ, R.* - BARThOLY, J. - MiKLÓs, E. \\ Eötvös Loránd University, Department of Meteorology \\ 1117 Budapest, Pázmány Péter sétány 1/A, Hungary \\ (phone: +36-1-372-2945; fax: +36-1-372-2904) \\ *Corresponding author \\ e-mail:prita@elte.hu
}

(Received $27^{\text {th }}$ October 2011; accepted $10^{\text {th }}$ November 2011)

\begin{abstract}
In order to estimate the future regional climate change for the Carpathian Basin located in Central/Eastern Europe, outputs from several RCMs (from the completed European project ENSEMBLES) are summarized and analyzed using the SRES A1B scenario. Composite maps of the projected annual and seasonal temperature and precipitation changes are generated using RCM simulations (with $25 \mathrm{~km}$ spatial resolution) for the reference period 1961-1990, and the target periods 2021-2050, 2071-2100. Overall, the results suggest significant warming in Hungary. Projected seasonal warming is $1-3{ }^{\circ} \mathrm{C}$, and $2-6{ }^{\circ} \mathrm{C}$ for $2021-2050$, and $2071-2100$, respectively. The largest temperature increase is likely to occur in summer. In case of precipitation, the annual sum is not likely to change significantly in the region. However, the summer precipitation is projected to decrease significantly during the 21 st century, autumn and winter precipitation amounts are projected to increase.
\end{abstract}

Keywords: regional climate modeling, climate change, ENSEMBLES project, temperature, precipitation

\section{Introduction}

Several recently increased regional environmental problems are related to climate change. The Intergovernmental Panel on Climate Change (IPCC) Assessment Reports summarize the global warming issues, detected changes, possible causes, global model projections, as well, as regional adaptation and mitigation strategies. Since the last IPCC report published in 2007, new model experiments with fine resolution have been completed and new results became available (e.g., van der Linden and Mitchell, 2009). For our region, previously $50 \mathrm{~km}$ horizontal resolution climate change analysis was summarized in Bartholy et al. (2007) using PRUDENCE outputs (Christensen et al., 2007 ) for the end of the 21 st century. In the recent years regional climate models (RCMs) were run with finer resolution and for longer time periods than previously. For a region with the size of the Carpathian Basin, RCMs are essential to provide appropriate details of climate variables. They are limited area models (Giorgi, 1990) nested in global climate models (GCMs), i.e., the initial and the boundary conditions of RCMs are provided by the GCM outputs. GCM outputs alone may be misleading to compose regional climate change scenarios due to their coarse spatial resolution, which is typically $100-200 \mathrm{~km}$. Evidently, this spatial resolution is not capable to describe regional climate processes (especially, the precipitation-related meteorological interactions and events), therefore, downscaling of GCM outputs is necessary in order to estimate future regional climatic trends. In this paper, new simulation results for Hungary and its vicinity are summarized and analyzed using the RCM experiments of the completed ENSEMBLES project (van der Linden and Mitchell, 2009). For the selected target region covering the latitude $44^{\circ}-50^{\circ} \mathrm{N}$, and longitude $14^{\circ}-26^{\circ} \mathrm{E}$, 
composite maps of projected temperature and precipitation changes are generated using the RCM simulations for the periods of 1961-1990 (as the reference period), 2021-2050, and 2071-2100.

First, the project ENSEMBLES is briefly introduced. Then, in order to estimate the bias of the different RCMs, ERA-40 driven runs are compared to the so-called E-OBS datasets (Haylock et al., 2009) containing gridded daily temperature and precipitation values. For the evaluation of annual, seasonal, and monthly projected climatic changes, GCM-driven runs of the reference and the future periods are compared.

Table 1. List of the participating institutes, their applied RCMs with the driving GCMs, and the completed simulation for $A 1 B(*$ on the right indicates the experiments used in this paper)

\begin{tabular}{|c|c|c|c|c|}
\hline Institute/Contact & Driving GCM & Regional model & Simulating period & \\
\hline $\begin{array}{l}\text { CNRM } \\
\text { M. Déqué }\end{array}$ & $\begin{array}{c}\text { ARPEGE } \\
\text { ARPEGE_RM5.1 }\end{array}$ & $\begin{array}{l}\text { ALADIN } \\
\text { ALADIN }\end{array}$ & $\begin{array}{l}1950-2100 \\
1950-2100\end{array}$ & * \\
\hline $\begin{array}{c}\text { KNMI } \\
\text { E. van Meijgaard }\end{array}$ & ECHAM5-r3 & RACMO & $1950-2100$ & * \\
\hline $\begin{array}{l}\text { OURANOS } \\
\text { D. Paquin }\end{array}$ & CGCM3 & CRCM & $1951-2050$ & \\
\hline $\begin{array}{c}\text { SMHI } \\
\text { E. Kjellström }\end{array}$ & $\begin{array}{c}\text { BCM } \\
\text { ECHAM5-r3 } \\
\text { HadCM3Q3 }\end{array}$ & $\begin{array}{l}\text { RCA } \\
\text { RCA } \\
\text { RCA }\end{array}$ & $\begin{array}{l}1961-2100 \\
1961-2100 \\
1961-2100\end{array}$ & * \\
\hline $\begin{array}{c}\text { MPI } \\
\text { D. Jacob }\end{array}$ & ECHAM5-r3 & REMO & $1951-2100$ & $*$ \\
\hline $\begin{array}{l}\text { 0METNO } \\
\text { J. E. Haugen }\end{array}$ & $\begin{array}{c}\text { BCM } \\
\text { HadCM3Q0 }\end{array}$ & $\begin{array}{l}\text { HIRHAM } \\
\text { HIRHAM }\end{array}$ & $\begin{array}{l}1951-2100 \\
1951-2100\end{array}$ & \\
\hline $\begin{array}{c}\text { C4I } \\
\text { R. McGrath }\end{array}$ & HadCM3Q16 & RCA3 & $1951-2100$ & $*$ \\
\hline $\begin{array}{c}\text { UCLM } \\
\text { M. de Castro }\end{array}$ & HadCM3Q0 & PROMES & $1951-2050$ & \\
\hline $\begin{array}{c}\text { ETHZ } \\
\text { C. Schär }\end{array}$ & HadCM3Q0 & CLM & $1951-2100$ & $*$ \\
\hline $\begin{array}{c}\text { HC } \\
\text { E. Buonomo }\end{array}$ & $\begin{array}{c}\text { HadCM3Q0 } \\
\text { HadCM3Q3 } \\
\text { HadCM3Q16 }\end{array}$ & $\begin{array}{c}\text { HadRM3Q0 } \\
\text { HadRM3Q3 } \\
\text { HadRM3Q16 }\end{array}$ & $\begin{array}{l}1951-2100 \\
1951-2100 \\
1951-2100\end{array}$ & $*$ \\
\hline $\begin{array}{c}\text { DMI } \\
\text { O. B. Christensen }\end{array}$ & $\begin{array}{c}\text { ARPEGE } \\
\text { ECHAM5-r3 } \\
\text { BCM }\end{array}$ & $\begin{array}{c}\text { HIRHAM } \\
\text { HIRHAM5 } \\
\text { HIRHAM5 }\end{array}$ & $\begin{array}{l}1951-2100 \\
1951-2100 \\
1957-2096\end{array}$ & * \\
\hline $\begin{array}{c}\text { ICTP } \\
\text { F. Giorgi }\end{array}$ & ECHAM5-r3 & $\mathrm{RegCM}$ & $1951-2100$ & $*$ \\
\hline $\begin{array}{l}\text { VMGO } \\
\text { I. Shkolnik }\end{array}$ & HadCM3Q0 & $\mathrm{RRCM}$ & $1951-2050$ & \\
\hline $\begin{array}{c}\text { GKSS } \\
\text { B. Rockel }\end{array}$ & IPSL & CLM & $1963-2050$ & \\
\hline
\end{tabular}

\section{The ENSEMBLES project}

The ENSEMBLES project (van der Linden and Mitchell, 2009) has been funded by the European Union 6th framework programme. The project was accomplished between 2004 and 2009 with the lead of the UK MetOffice, and 66 other institutes from 20 countries (mostly from Europe) participated. The main aims of the research program 
were as follows: (i) to develop an ensemble climate prediction system on seasonal to centennial time-scales; (ii) to quantify and reduce the uncertainty in modelling climate change; (iii) to link the outputs of the ensemble prediction system to a range of applications. For all these purposes an intermediate emission scenario has been selected, namely, SRES A1B (Nakicenovic and Swart, 2000). According to this scenario fast economical and technological development is projected, the world population is estimated to increase by the mid-century up to 9 million, then slightly decrease by the end of the 21 st century to 7 million. The energy demand is estimated to be fulfilled both from fossil fuels and renewable and/or nuclear sources. As a consequence, $\mathrm{CO}_{2}$ content of the atmosphere continues to increase in the coming decades. The estimated $\mathrm{CO}_{2}$ concentration levels by 2050 and by 2100 are 532 ppm, and 717 ppm, respectively.

Table 1 summarizes the completed RCM experiments with $25 \mathrm{~km}$ horizontal resolution. In the present analysis $11 \mathrm{RCM}$ experiments are used, they all were run for the entire 1951-2100 period. The driving lateral and boundary conditions are provided by three different GCMs, namely, (i) ECHAM developed by the Max Planck Institute in Hamburg (Roeckner et al., 2006), (ii) HadCM developed by the UK MetOffice Hadley Centre (Gordon et al., 2000; Rowell, 2005), and (iii) ARPEGE developed by MétéoFrance (Déqué et al., 1998).

\section{Validation of RCM results}

In order to estimate the bias of the different RCMs, ERA-40 (European Centre for Medium-range Weather Forecast, ECMWF, re-analysis dataset described in Uppala et al., 2005) driven runs are compared to the E-OBS datasets (Haylock et al., 2008) containing observation-based daily temperature and precipitation values for Europe. In case of each RCM experiment, monthly mean bias values have been calculated for each grid point located in Hungary, and then, the spatial averages for the country have been determined for all months. Figs. 1 and 2 compare the total numbers of months, in which the RCM results over/underestimate significantly (at 0.05 level using t-test) the average temperature or precipitation values calculated from E-OBS data. Although 11 RCM experiments are analyzed for the future, two of them (i.e., RCA, HIRHAM) were run using different GCMs. Therefore, only 9 ERA-40 driven RCM validation runs are necessary to evaluate.

In case of temperature (Fig. 1), three models (HadRM3Q, RCA3, RCA) can be considered bias-free, i.e., the monthly differences between the RCM outputs and the EOBS data are not significant at 0.05 level and do not exceed $1{ }^{\circ} \mathrm{C}$ in any month. The most overestimations (in 7 months) can be identified in REMO simulations (from May to November). Moreover, RegCM outputs significantly underestimate the monthly mean temperature calculated from E-OBS data in 4 months (February, March, April, and October). 


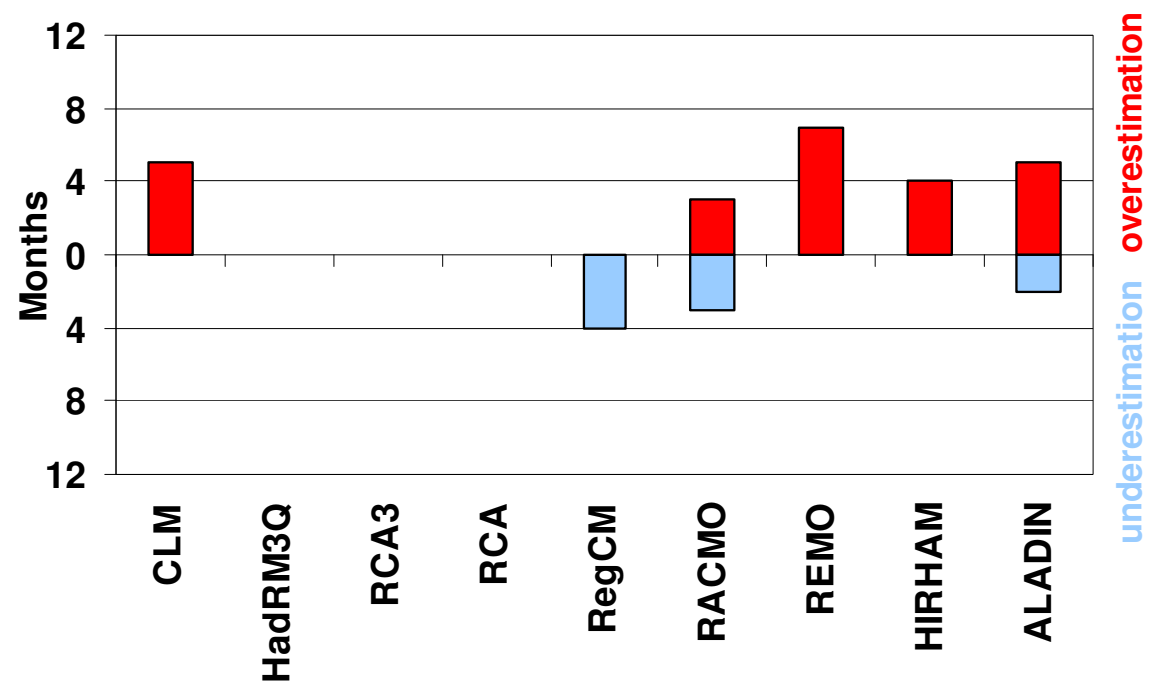

Figure 1. Validation of temperature in case of the ERA40-driven RCM experiments (1961-1990)

In case of monthly precipitation (Fig. 2), RCMs are less successful in reconstructing current climatic conditions than in case of monthly temperature. The HadRM3Q is the only model that can be considered bias-free, i.e., the monthly differences between the RCM outputs and the E-OBS data are not significant at 0.05 level, and do not exceed 10 $\mathrm{mm}$. In general, RCM simulations significantly overestimate monthly precipitation. In case of models RegCM, RCA3, RCA, CLM, and HIRHAM, simulated precipitation is significantly larger than the E-OBS data in most part of the year (especially, in winter and early spring). However, most RCMs underestimate the monthly precipitation in a month or two (typically in August). The most underestimation appears in case of ALADIN simulations (in 6 months: from August to December).

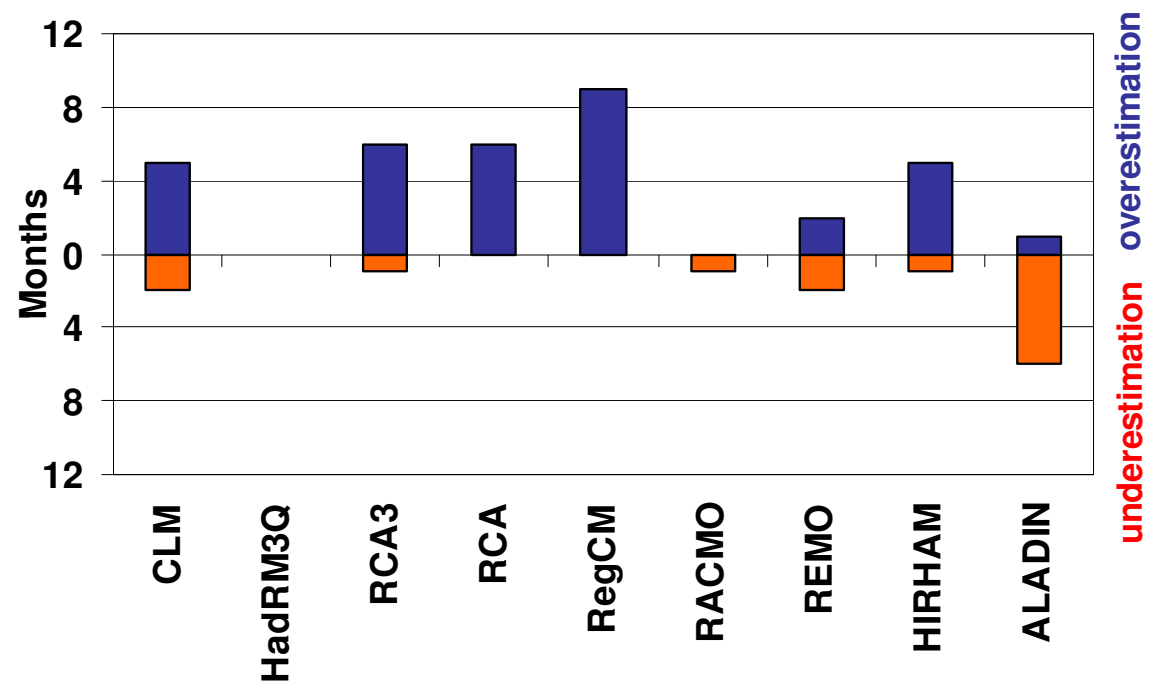

Figure 2. Validation of precipitation in case of the ERA40-driven RCM experiments (1961-1990) 
Overall, the validation results suggest that the RCMs are generally able to reconstruct the temperature sufficiently. In case of precipitation, simulated values often significantly overestimate the observations.

\section{Analysis of future regional temperature trends}

For the evaluation of annual, seasonal, and monthly projected climatic changes, GCM-driven runs of the reference and the future periods are compared. Figs. 3-5 show the annual and seasonal mean projected warming for Hungary for each RCMs. All projected temperature changes are significant at 0.05 level using t-test.

All the ECHAM driven RCMs (Fig. 3) project $0.7-1.7{ }^{\circ} \mathrm{C}$ and $1.9-4.0{ }^{\circ} \mathrm{C}$ seasonal and annual warming by 2021-2050 and 2071-2100, respectively. The largest annual increase is projected by REMO for both period. In case of seasonal warming, the largest rate is likely to occur in summer and autumn by the middle of the 21 st century, while in summer and winter by the end of the 21 st century.
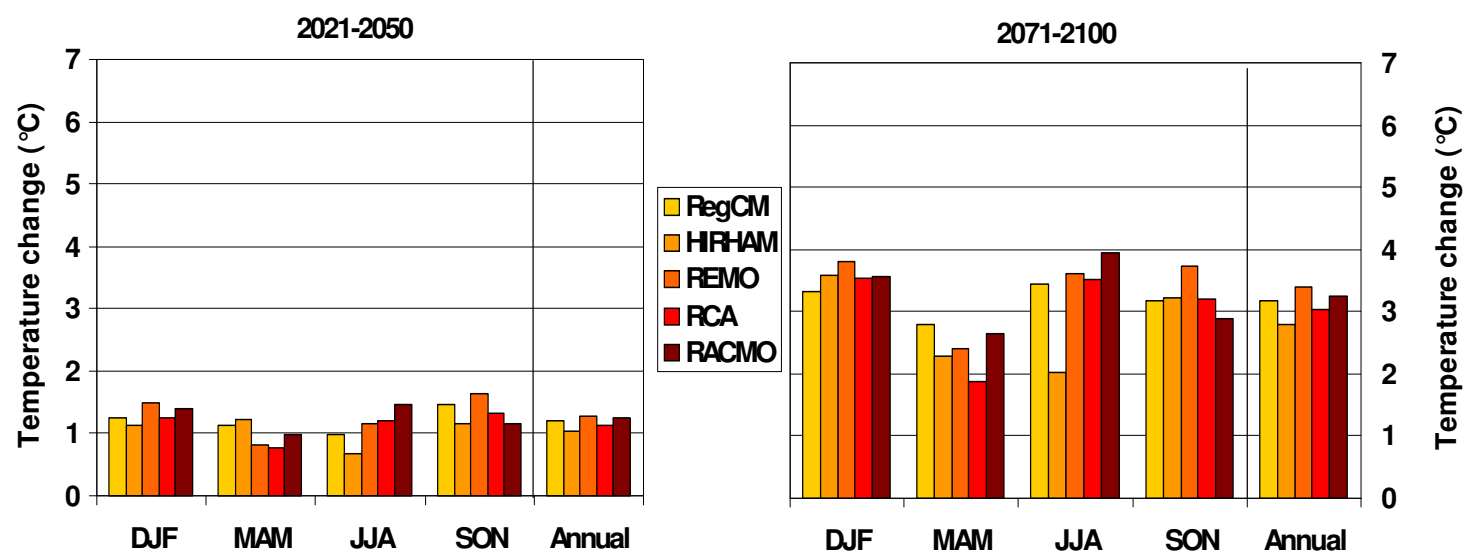

Figure 3. Projected temperature changes for Hungary by 2021-2050 and 2071-2100 using ECHAM as driving GCM (reference period: 1961-1990). All seasonal and annual changes are significant at 0.05 level

The HadCM-driven RCMs (Fig. 4) project larger increase in temperature than the ECHAM-driven RCMs. By the mid-century the simulations suggest $1.1-3.4{ }^{\circ} \mathrm{C}$ seasonal warming, which are likely to double by the late-century (up to $2.2-6.4{ }^{\circ} \mathrm{C}$ ). The largest seasonal warming is clearly projected by HadRM3Q experiment for summer. Moreover, the largest annual warming is also simulated by HadRM3Q $\left(2.5^{\circ} \mathrm{C}\right.$ and $5.0{ }^{\circ} \mathrm{C}$ by 2021 2050 and 2071-2100, respectively). HadCM-driven RCMs project the largest temperature increase for summer and winter by the near future, and mostly for summer by the end of the 21 st century (except RCA).

In case of ARPEGE-driven RCMs (Fig. 5), the projected seasonal changes by 20212050 and 2071-2100 are 0.8-2.1 ${ }^{\circ} \mathrm{C}$, and 1.7-5.0 ${ }^{\circ} \mathrm{C}$, respectively. In general, the ALADIN experiment results greater warming than the HIRHAM experiment. The largest seasonal increase is projected for summer in both future period, and by both RCMs. 


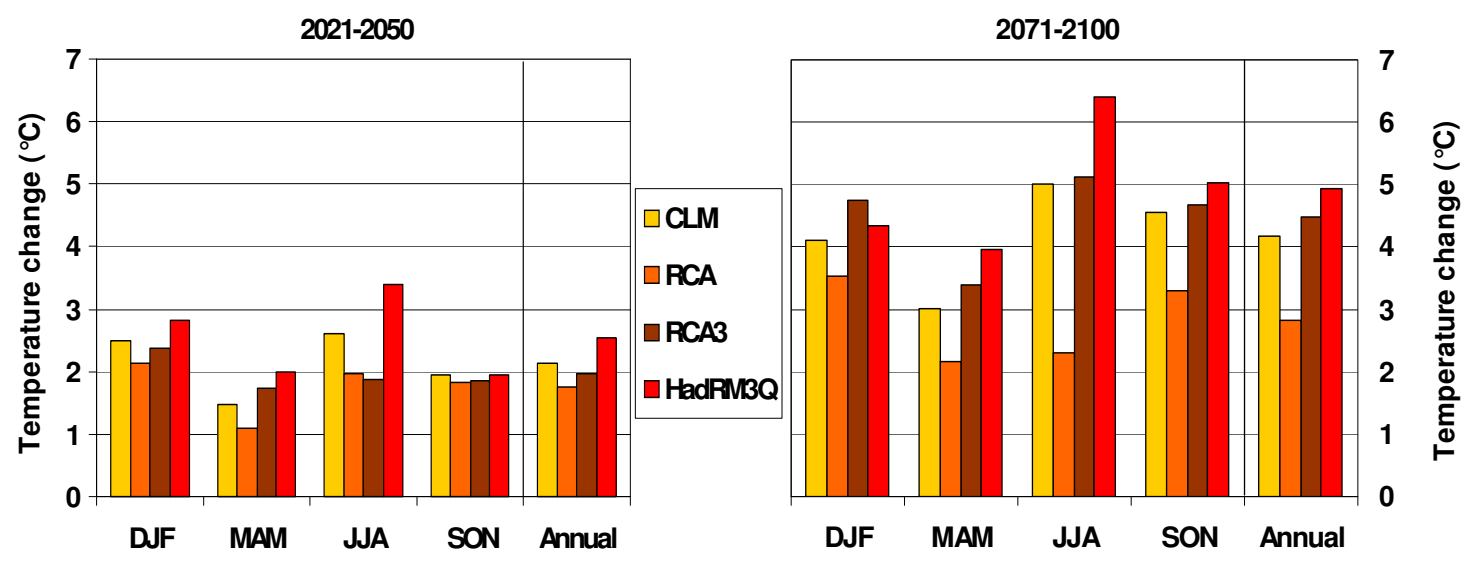

Figure 4. Projected temperature changes for Hungary by 2021-2050 and 2071-2100 using HadCM as driving GCM (reference period: 1961-1990). All seasonal and annual changes are significant at 0.05 level

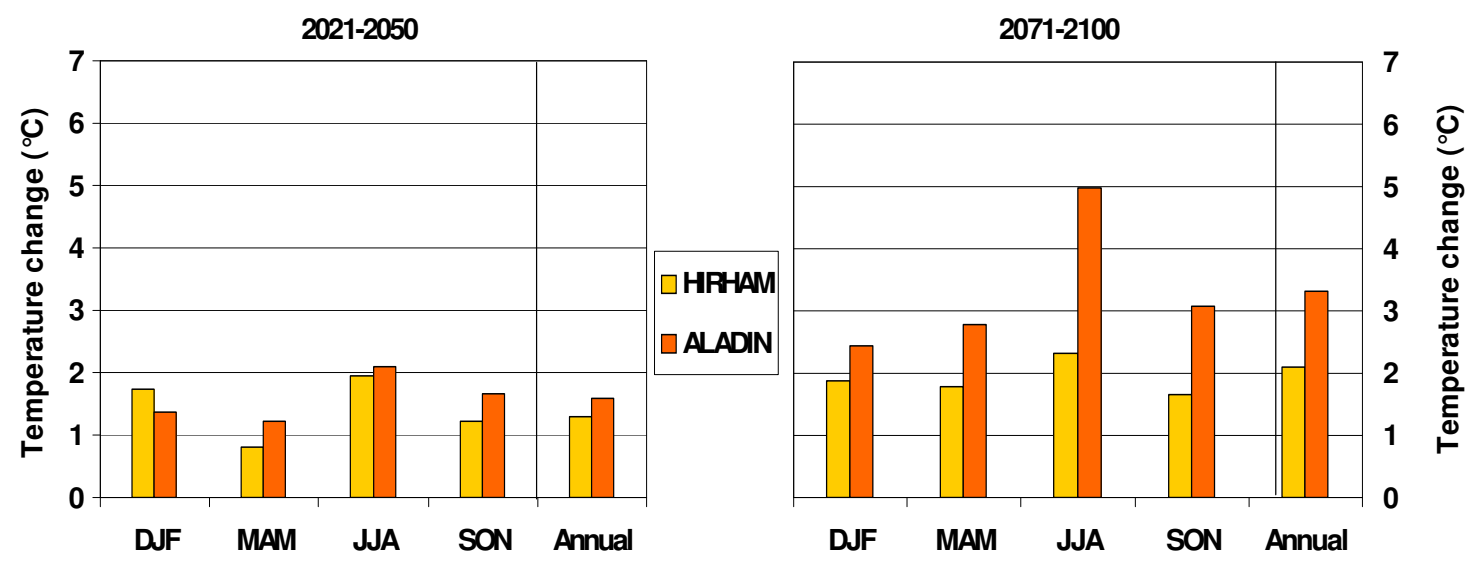

Figure 5. Projected temperature changes for Hungary by 2021-2050 and 2071-2100 using ARPEGE as driving GCM (reference period: 1961-1990). All seasonal and annual changes are significant at 0.05 level

Fig. 6 presents the seasonal spatial structure of composite maps calculated from projected seasonal temperature changes by the mid- and late-century for all the $11 \mathrm{RCM}$ experiments considered in this analysis. In summer and autumn zonal structures can be recognized, the simulated changes are likely to increase from north to south. The projected changes by $2021-2050$ are $1.2-1.8{ }^{\circ} \mathrm{C}$. The largest warming is likely to occur in autumn in the southern/southeastern part of the country. The smallest increase is projected for spring. By 2071-2100 the projected seasonal changes are $2.6-4.0{ }^{\circ} \mathrm{C}$. The largest warming is projected in summer and autumn, and the smallest in spring. 

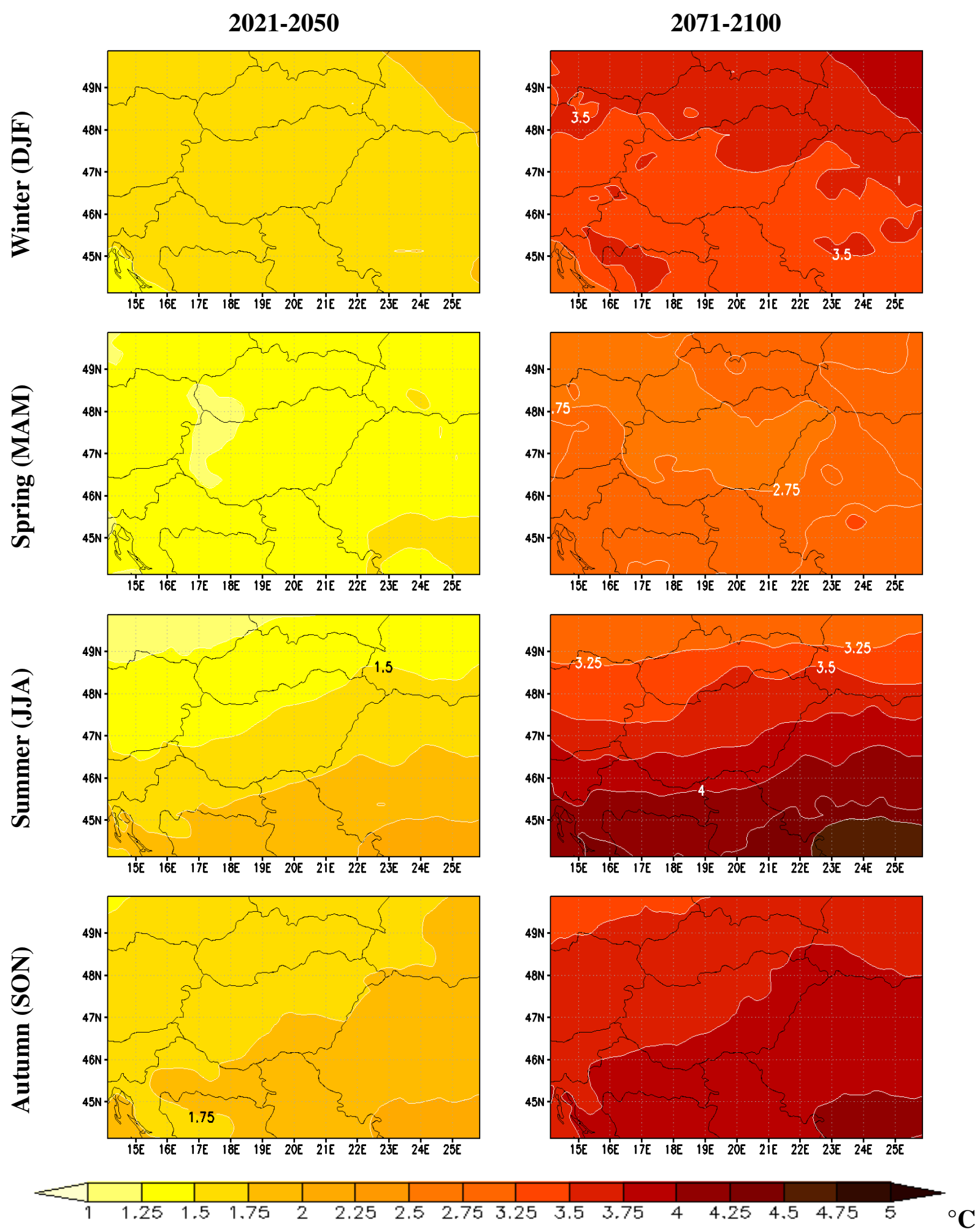

Figure 6. Composite map of the projected seasonal mean temperature changes $\left({ }^{\circ} \mathrm{C}\right)$ by 2021-2050 and 2071-2100 (reference period: 1961-1990) 


\section{Analysis of future regional precipitation trends}

Annual and seasonal mean projected precipitation changes for Hungary are shown in Figs. 7-9, separated according to the driving GCMs. All the changes being significant at 0.05 level using t-test are marked on the graphs (using an asterisk). More estimated changes are significant by 2071-2100 than by 2021-2050 due to the more clear climate change signal.

All the ECHAM-driven RCMs project precipitation increase in winter (by 20-30\%) and autumn (by 15-25\%), and decrease in summer (by 5-25\%) for both periods (Fig. 7). Most of these projections are significant by 2071-2100, unlike by 2021-2050. According to these experiments, overall, the Hungarian climate is projected slightly wetter by the late 21 st century, the estimated annual precipitation increase do not exceed $10 \%$, and it is significant only in the case of RegCM and HIRHAM simulations.
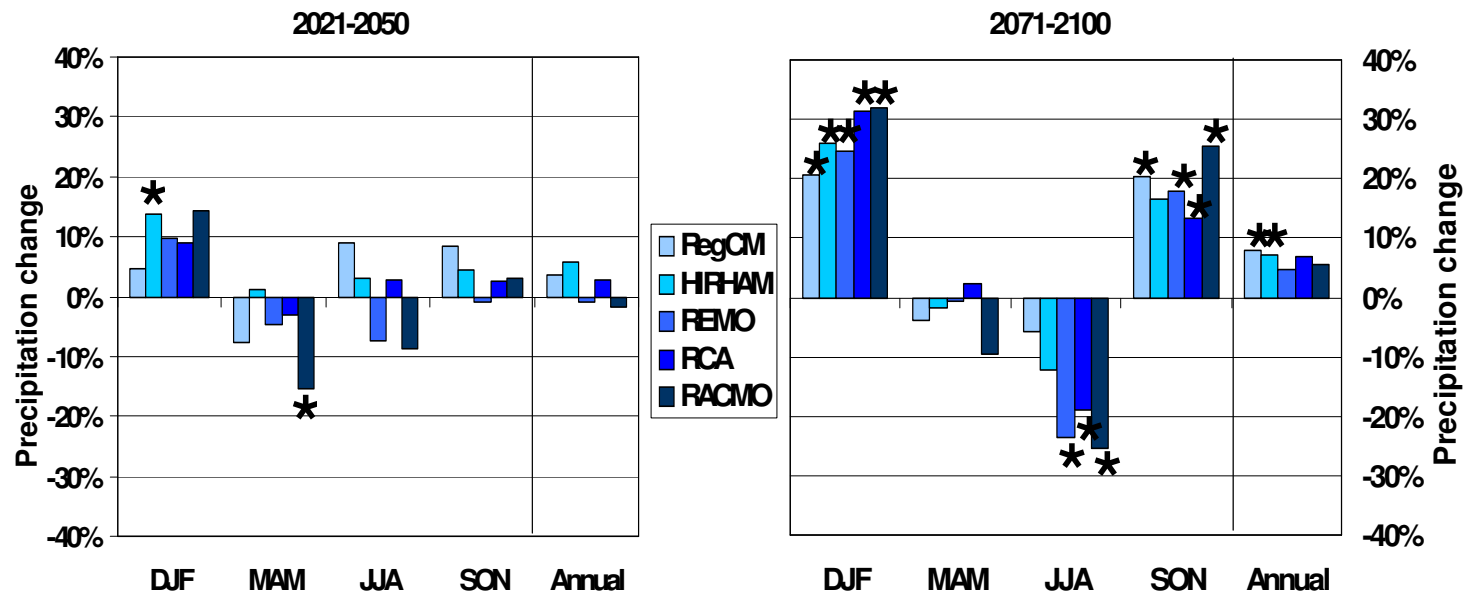

Figure 7. Projected precipitation changes for Hungary by 2021-2050 and 2071-2100 using ECHAM as driving GCM (reference period: 1961-1990). Significant seasonal and annual changes are indicated by ' *'

Similarly to the ECHAM-driven experiments, HadCM-driven RCM simulations project wetter winters and drier summers (Fig. 8) for the future than the present conditions. The estimated winter increase and summer decrease by $2071-2100$ is $7-27 \%$ and $3-41 \%$, respectively. However, less of these projected changes are significant than those by the RCMs shown in Fig. 7. On the other hand, among all the 11 RCM experiments discussed in the present paper, CLM and HadRM3Q simulations project the largest precipitation decrease ( 40\%).

Only two RCM experiments are driven by ARPEGE, namely, HIRHAM and ALADIN. Most of their seasonal precipitation projections for Hungary are not significant at 0.05 level. However, the significant summer drying estimated by the other GCM-driven RCM simulations is also projected by both ARPEGE-driven RCMs (Fig. 9). The estimated average precipitation decrease for the entire country is $4 \%$ (HIRHAM) and 28\% (ALADIN). Overall, a slight annual precipitation decrease (by about $10 \%$ ) is also projected for the country by 2071-2100, which is significant in case of ALADIN simulations. Unlike the other GCM-driven RCM experiments, these two RCM simulations do not project significant changes in winter neither by the middle, nor the end of the 21 st century. 

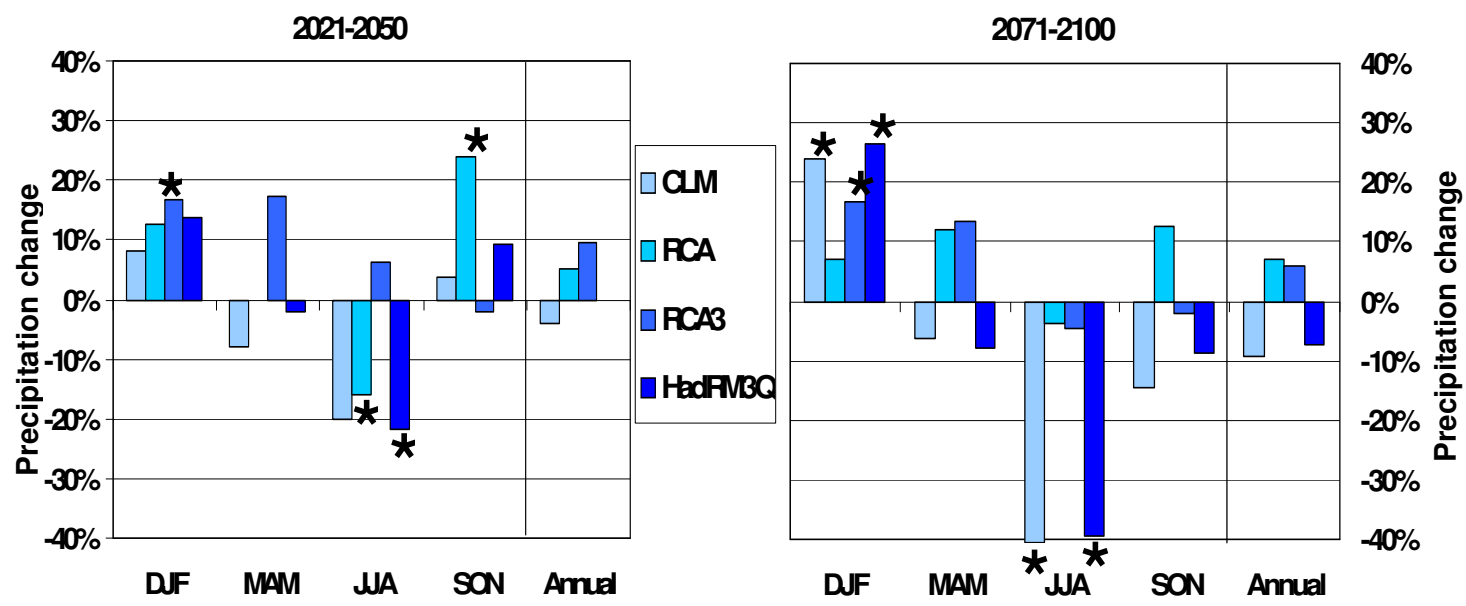

Figure 8. Projected precipitation changes for Hungary by 2071-2100 using HadCM as driving GCM (reference period: 1961-1990). Significant seasonal and annual changes are indicated by ' *'

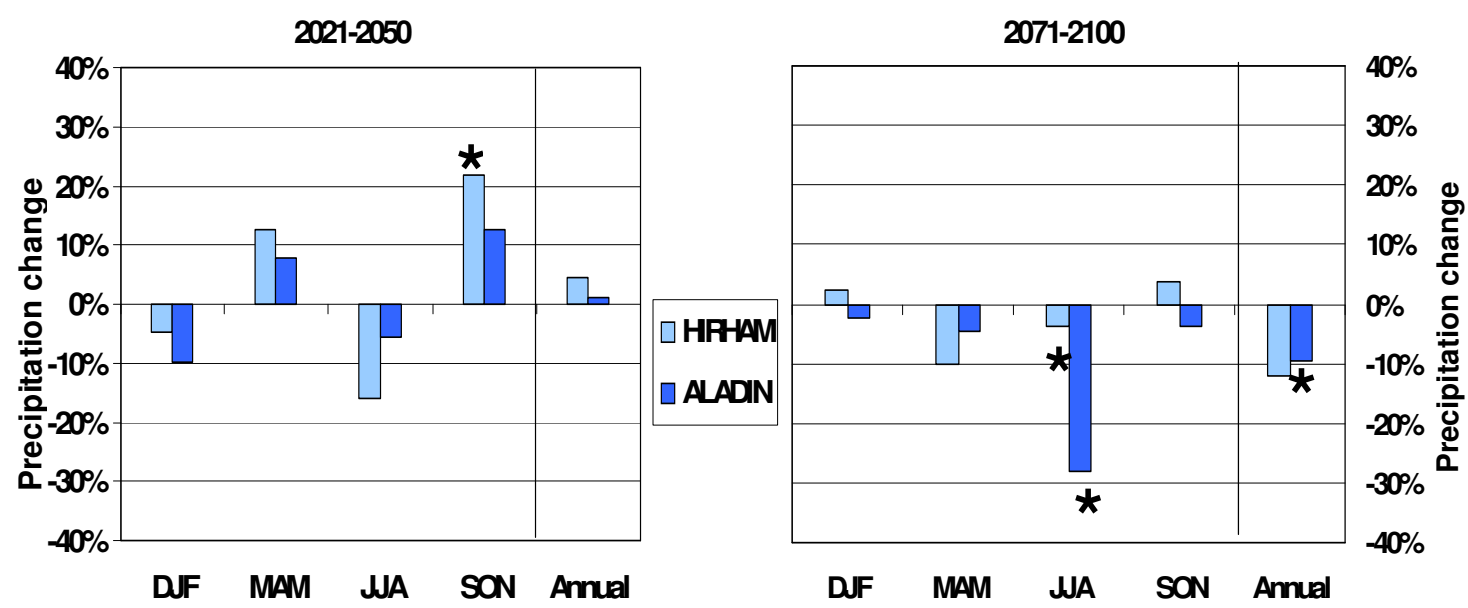

Figure 9. Projected precipitation changes for Hungary by 2071-2100 using ARPEGE as driving GCM (reference period: 1961-1990). Significant seasonal and annual changes are indicated by ' *'

Fig. 10 presents the seasonal spatial structure of composite precipitation changes for the mid- and the late-century using all the 11 RCMs considered in this paper. The composite maps clearly suggest drier summers and wetter climatic conditions for the other three seasons for both future periods compared to the 1961-1990 reference period. The estimated changes are larger (by about a factor of 2) for 2071-2100 than for 20212050. The largest precipitation increase by the middle and the end of this century is projected for autumn (7-12\%) and for winter (14-19\%), respectively. The rate of precipitation change in autumn increase from southwest to northwest for both periods. As the spatial average changes already suggested, summers are very likely to become drier in the coming decades. Nevertheless, spatial differences within Hungary can be identified in the composite maps. Future summers are projected much drier in the southeastern part of the country than in the northwestern region. By the late century the 
estimated seasonal precipitation decrease exceeds $20 \%$ in the southeastern part of the Great Hungarian Plain.
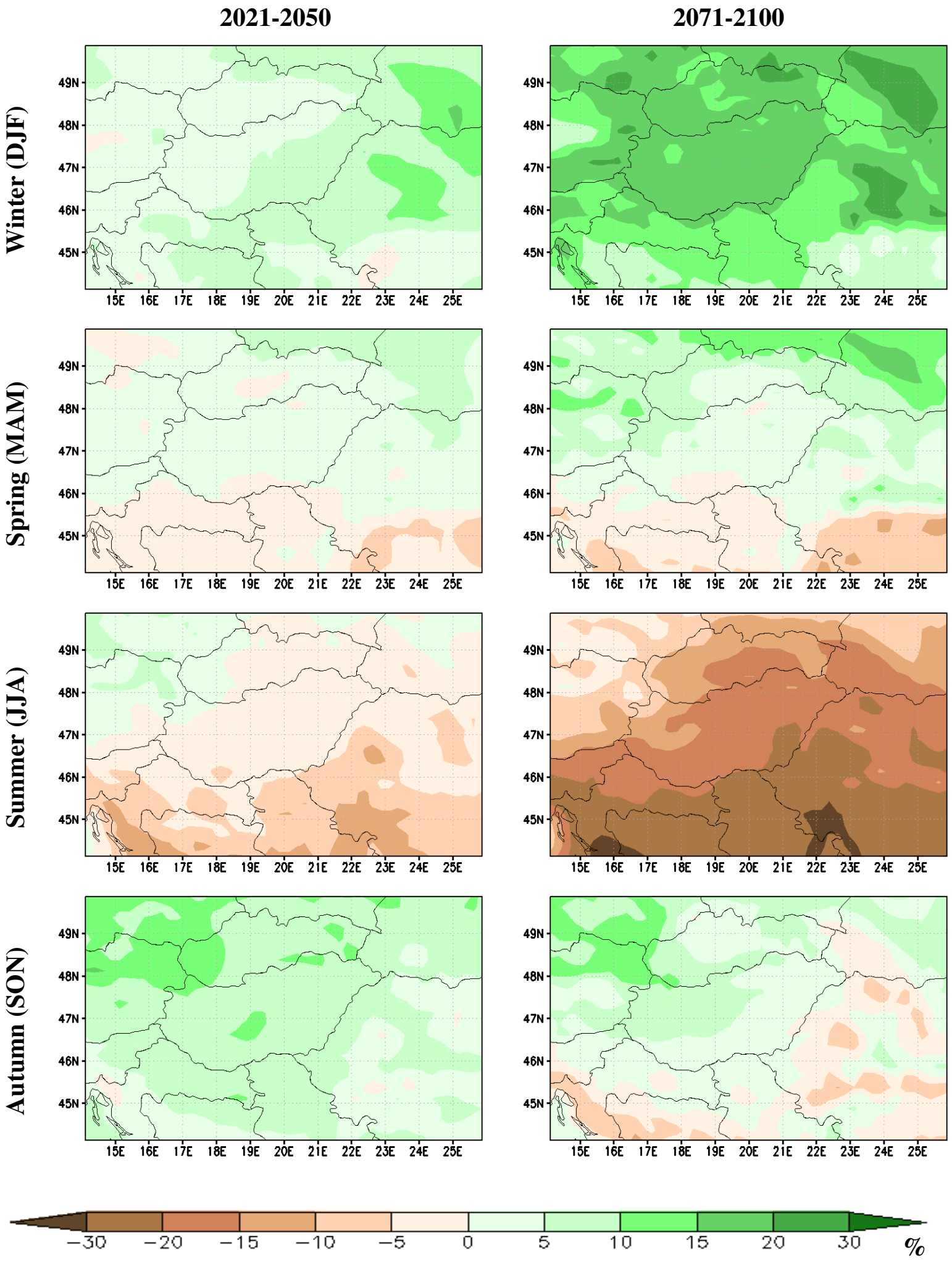

Figure 10. Composite map of the projected seasonal mean precipitation changes (\%) by 2021-2050 and 2071-2100 (reference period: 1961-1990) 
Finally, in spring the composite maps indicate wetter conditions in the northern part of the selected domain and drier climate in the southern regions compared to the 19611990 reference period. In the gridpoints located within the borders of Hungary the estimated seasonal changes are small and not significant.

\section{Conclusions}

Based on the regional climate change analysis discussed for Hungary in this paper, the following conclusions can be drawn.

(i) All of the evaluated RCM simulations from the project ENSEMBLES suggest that the temperature is very likely to increase significantly in the future in all months and seasons. The projected annual warming is about $1-2.5{ }^{\circ} \mathrm{C}$, and $2-5{ }^{\circ} \mathrm{C}$ for $2021-2050$, and 2071-2100, respectively. Annual and seasonal mean projected changes for Hungary are summarized in Fig. 11, the different driving GCMs are also indicated.

(ii) Most of the RCMs suggest that the winter and autumn precipitation is likely to increase (Fig. 12), while summer precipitation is projected to decrease during the 21st century. The mean change by $2021-2050$ is not likely to exceed $20 \%$ in any season. By 2071-2100 remarkable winter precipitation increase (10-30\%) and significant summer precipitation decrease (15-40\%) are projected for Hungary.

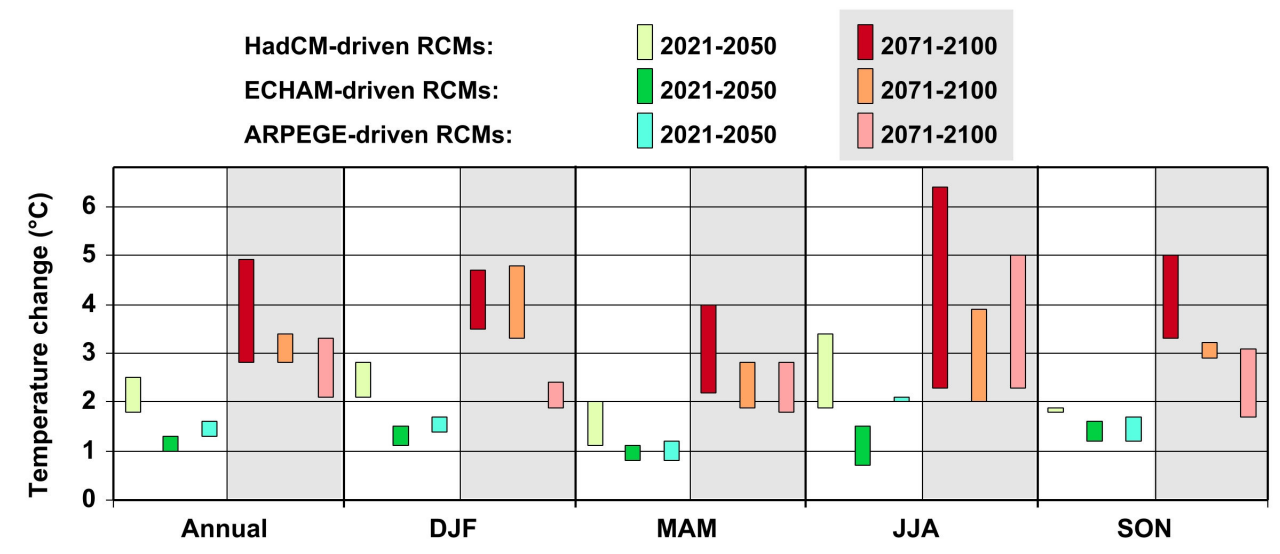

Figure 11. Summary of projected temperature changes for Hungary by 2021-2050 and 2071-2100 separated according to the driving GCM (reference period: 1961-1990)

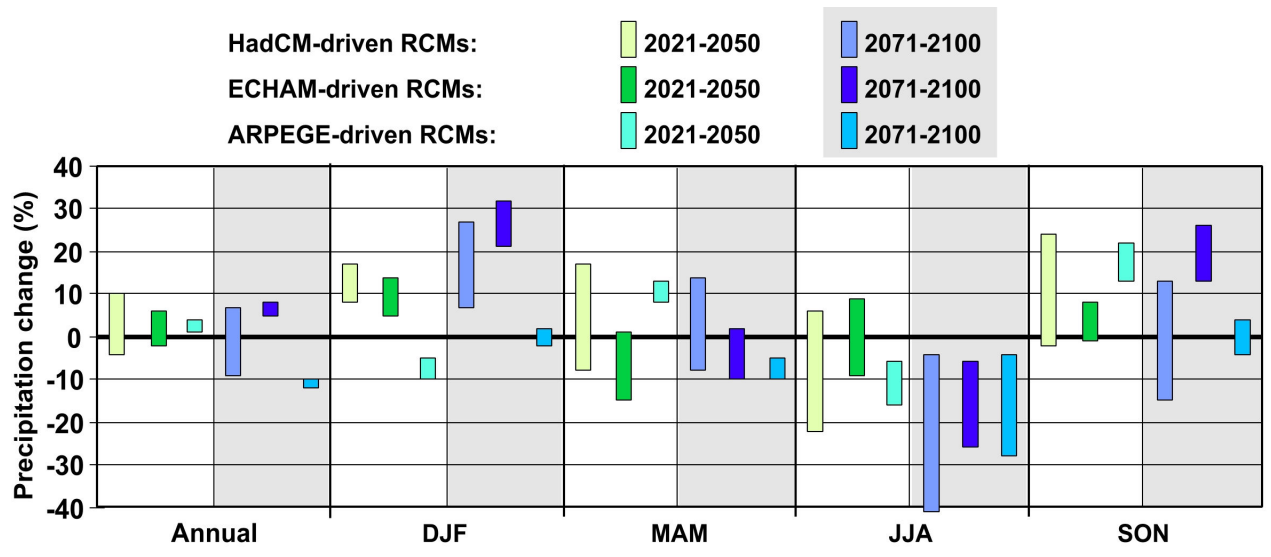

Figure 12. Summary of projected precipitation changes for Hungary by 2021-2050 and 2071-2100 separated according to the driving GCM (reference period: 1961-1990) 
Acknowledgements. Research leading to this paper has been supported by the following sources: the Hungarian Academy of Sciences under the program 2006/TKI/246 titled Adaptation to climate change, the Hungarian National Science Research Foundation under grants T-049824, K-69164, K-78125, and K67626, the Hungarian Ministry of Environment and Water under the National Climate Strategy Development project, the CC-WATERS project of the European Regional Development Fund (SEE/A/022/2.1/X), the European Union and the European Social Fund (TÁMOP-4.2.1/B-09/1/KMR2010-0003).

\section{REFERENCES}

[1] Bartholy, J., Pongrácz, R., Gelybó, Gy. (2007): Regional climate change expected in Hungary for 2071-2100. - Applied Ecology and Environmental Research 5: 1-17.

[2] Déqué, M., Marquet, P., Jones, R.G. (1998): Simulation of climate change over Europe using a global variable resolution general circulation mode. - Climate Dyn. 14: 173-189.

[3] Giorgi, F. (1990): Simulation of regional climate using a limited area model nested in a general circulation model. - J. Climate 3: 941-963.

[4] Gordon, C., Cooper, C., Senior, C.A., Banks, H., Gregory, J.M., Johns, T.C., Mitchell, J.F.B., Wood, R.A. (2000): The simulation of SST, sea ice extents and ocean heat transports in a version of the Hadley Centre coupled model without flux adjustments. Climate Dynamics 16: 147-168.

[5] Haylock, M.R., Hofstra, N., Klein Tank, A.M.G., Klok, E.J., Jones, P.D., New, M. (2008): A European daily high-resolution gridded dataset of surface temperature and precipitation. - J. Geophys. Res (Atmospheres) 113, D20119, doi:10.1029/2008 JD10201.

[6] Nakicenovic, N., Swart, R. (2000): Emissions Scenarios. A special reports of IPCC Working Group III. - Cambridge University Press, UK. 570p.

[7] Roeckner, E., Brokopf, R., Esch, M., Giorgetta, M., Hagemann, S., Kornblueh, L., Manzini, E., Schlese, U., Schulzweida, U. (2006): Sensitivity of simulated climate to horizontal and vertical resolution in the ECHAM5 atmosphere model. - J. Climate 19: 3771-3791.

[8] Rowell, D.P.(2005): A scenario of European climate change for the late 21st century: seasonal means and interannual variability. - Climate Dynamics 25: 837-849.

[9] Uppala, S.M., Kallberg, P.W., Simmons, A.J., Andrae, U., da Costa Bechtold, V., Fiorino, M., Gibson, J.K., Haseler, J., Hernandez, A., Kelly, G.A., Li, X., Onogi, K., Saarinen, S., Sokka, N., Allan, R.P., Andersson, E., Arpe, K., Balmaseda, M.A., Beljaars, A.C.M., van de Berg, L., Bidlot, J., Bormann, N., Caires, S., Chevallier, F., Dethof, A., Dragosavac, M., Fisher, M., Fuentes, M., Hagemann, S., Holm, E., Hoskins, B.J., Isaksen, L., Janssen, P.A.E.M., Jenne, R., McNally, A.P., Mahfouf, J.-F., Morcrette, J.-J., Rayner, N.A., Saunders, R.W., Simon, P., Sterl, A., Trenberth, K.E., Untch, A., Vasiljevic, D., Viterbo, P., Woollen, J. (2005): The ERA-40 re-analysis. - Quart. J. R. Meteorol. Soc. 131: 2961-3012. doi:10.1256/qj.04.176.

[10] van der Linden, P., Mitchell, J.F.B. (eds.) (2009): ENSEMBLES: Climate Change and Its Impacts: Summary of research and results from the ENSEMBLES project. - UK Met Office Hadley Centre, Exeter, UK, 160p. 